\title{
SOCIOEMOCIONALNA POSVEĆENOST RODITELJA DECE SA SMETNJAMA U RAZVOJU: RAZLIKE IZMEĐU MAJKI I OČEVA ${ }^{1}$
}

Apstrakt: Cilj ovog istraživanja je bio da se ispita da li postoje statistički značajne razlike u socioemocionalnoj posvećenosti između roditelja dece sa smetnjama u razvoju i roditelja dece tipičnog razvoja, i na kojim dimenzijama socioemocionalne posvećenosti su te razlike najizraženije. Takođe ispitan je i efekat pola na kvalitet socioemocionalne posvećenosti obe grupe roditelja. U istraživanju je učestvovalo 202 roditeljska para, a od toga je bilo 75 parova roditelja dece sa smetnjama u razvoju, za koje je izrađen individualni obrazovni plan i 127 parova roditelja dece tipičnog razvoja. Podaci su prikupljeni u predškolskim ustanovama, na području Vojvodine. Kao mera kvaliteta socioemocionalne posvećenosti roditelja korišćen je Upitnik o socioemocionalnoj posvećenosti roditelja (PIC-Parent Investment in Child, Bradley 1997). Dobijeni rezultati ukazuju na statistički značajno niži kvalitet socioemocionalne posvećenosti kod roditelja dece sa smetnjama u razvoju $(\mathrm{F}=10.72 ; \mathrm{df}(1) ; \mathrm{p}<.01)$. Analizom razlika u socioemocionalnoj posvećenosti pokazano je da je prihvatanje roditeljske uloge dimenzija po kojoj se dve grupe roditelja najviše razlikuju $(w \lambda=0.94, \mathrm{~F}(4,346)=5.68, \mathrm{p}<.01)$. Dobijeni rezultati interpretirani su u skladu sa teorijskim polazištem i nalazima ranijih istraživanja, ali i u svetlu implikacija za planiranje podrške za ove porodice.

Ključne reči: Roditelji dece sa smetnjama u razvoju, kvalitet brige, socioemocionalna posvećenost

Još je Bolbi u svojim radovima postavio hipotezu da formirani unutrašnji radni model brige ima značajan efekat na roditeljsko ponašanje, a roditeljsko ponašanje ima značajan efekat na razvojne ishode deteta (Bowlby, 1982). Unutrašnji radni model brige, koncept potekao iz teorije afektivne vezanosti, važna je kognitivna struktura koja deluje na nesvesnom nivou, njegov razvoj počinje još u ranoj interakciji sa figurnom vezanosti (Hanak, 2012.) i on se sastoji od reprezentacija sebe kao roditelja, uopšteno i na nivou roditelja specifičnog deteta, kao i reprezentacija specifičnog detata koje traži brigu (Solomon \& George, 1996). Ove

\footnotetext{
Istraživanje je nastalo u okviru projekta „Efekti egzistencijalne nesigurnosti na pojedinca i porodicu u Srbiji“, koji finansira Ministarstvo prosvete, nauke i tehnološkog razvoja (broj projekta 179022, rukovodilac dr Marija Zotović); adresa prvog autora: rajicmilana@gmail.com
} 
reprezentacije se formiraju još u periodu trudnoće, najčešće su idealizovane te se stoga nakon rođenja deteta pred roditelja stavlja zadatak da ih promeni u skladu sa zahtevima brige o realnom detetu. Funkcija unutrašnjeg radnog modela brige je da osigura bezbednost deteta, njegovu sreću i zadovoljstvo i da ga osposobi da opstane u svetu i uklopi se u socijalni kontekst (Mayseless, 2006). Po svemu sudeći, senzitivan roditelj je onaj koji ima kapaciteta da svoj unutrašnji radni model prilagodi prema karakteristikama deteta i razvojnim potrebama deteta koje su promenljive (Slade, Belsky, Aber, \& Phelps, 1999).

Dugo se senzitivnost izdvajala kao najznačajniji činilac razvoja sigurne afektivne vezanosti, u smislu dostupnosti roditelja, fizičke i mentalne, responsivnosti i sposobnosti interpretacije i adekvatnog reagovanja na detetova ponašanja traženja brige (Ainsworth, 1979). Kako je pokazano da senzitivnost objašnjava tek $23 \%$ veze između unutrašnjeg radnog modela majke i obrasca afektivne vezanosti deteta (Belsky, 1999), novija istraživanja su doprinela uvođenju novih varijabli u razumevanje činilaca razvoja sigurne afektivne vezanosti, kao na primer afektivna vezanost roditelja, potrebe roditelja i sl. Danas se kao jedan od mogućih načina operacionalizacije karakteristika kontrolnog sistema brige roditelja navodi socioemocionalna posvećenost, koja se kroz literaturu najčešće definiše preko manifestnih ponašanja roditelja, koja podrazumevaju: radost $i$ zadovoljstvo roditelja u interakciji sa detetom, želju da se provodi vreme sa detetom, osetljivost na potrebe deteta, brigu za dobrobit deteta, prihvatanje deteta i uloge roditelja i doslednu potrebu da se reaguje u skladu sa najboljim interesima deteta (Bradley, Whiteside-Mansell, Brisby, Caldwell, 1997). Socioemocionalna posvećenost se zapravo može posmatrati kao stepen u kom je roditelj posvećen svojoj ulozi i predan brizi o detetu u cilju obezbeđivanja optimalnih uslova za razvoj. Roditelji sa višim stepenom socioemocionalne posvećenosti se prepoznaju kao više investirani u odnos sa detetom, stimulativni su i pružaju detetu više podrške (Bradley et al., 1997). Ovaj odnos se kroz istraživanja pokazao stabilnim tokom ranog detinjstva (Corwyn \& Bradley, 2002).

U porodicama pod rizikom senzitivnost $\mathrm{i}$ kvalitet brige su često narušeni usled uticaja različitih psiholoških i sociodemografskih faktora, kao što je nizak socioekonomski status, slab kvalitet socijalne podrške i sl. To posledično vodi većoj stopi razvoja nesigurnih obrazaca afektivne vezanosti (Choe, Olson \& Sameroff, 2013). Nesiguran obrazac afektivne vezanosti se kroz istraživanja pokazao kao značajan činilac koji doprinosi slabijem kvalitetu kognitivnog i socioemocionalnog razvoja deteta (Dexter, Wong, Stacks, Beeghly, \& Barnett, 2012). U populaciji dece tipičnog razvoja, siguran obrazac se javlja u više od polovine slučajeva, dok se u populaciji dece sa smetnjama u razvoju on javlja u manje od polovine slučajeva (Clements \& Barnett, 2002; van Ijzendoorn, Goldberg, Kroonenberg \& Frenkel, 1992). Neki od nalaza ranijih istraživanja koja su se pretežno bavila kvalitetom odnosa roditelj-dete, u porodicama dece sa smetnjama u razvoju, nude perspektivu da kod njih razvoj nesigurnog obrasca afektivne vezanosti ima više veze sa roditeljem i njegovim blagostanjem, nego sa samim detetom i konkretnom smetnjom (Howe, 2006). 
Kako je reorganizacija unutrašnjeg radnog modela brige nužna nakon rođenja realnog deteta, u većoj ili manjoj meri, tranzicija u roditeljstvo je razvojno očekivana kriza i od novih roditelja zahteva značajne napore. U porodicama dece sa smetnjama u razvoju, situacija je drugačija utoliko što roditelji najčešće i ne znaju da dete ima neke razvojne teškoće do porođaja, pa čak i prvih par godina nakon rođenja deteta, u zavisnosti od konkretne razvojne smetnje. Oni kao i svi drugi roditelji organizuju svoj radni model brige u skladu sa predstavom o idealnom detetu. Nakon šoka koji roditelji bez sumnje dožive pri saznavanju dijagnoze, da bi reorganizovali svoj model brige u skladu sa brigom o realnom detetu sa hroničnim razvojnim smetnjama, potrebno je da se adaptiraju na saznanje dijagnoze deteta. Ta adaptacija podrazumeva rešavanje zadatka kognitivne i emocionalne prorade dijagnoze i implikacija dijagnoze na dalji razvoj deteta i funkcionisanje porodice u budućnosti (Barnett, Clements, Kaplan-Estrin, \& Fialka, 2003). Roditelj koji je prihvatio-razresio, dijagnozu deteta sa svim njenim implikacijama, moze da bude realističan u odnosu na zdravstveno stanje i sposobnosti deteta, može da prepozna mogućnosti i ograničenja svog deteta, da uspešno uskladi svoju roditeljsku ulogu sa detetovim potrebama, te da bude senzitivan na potrebe deteta. Ako roditelj nije razrešen $u$ odnosu na dijagnozu deteta, on ne napreduje u toku vremena, od početka krize, fokusira se na trenutak saznavanja i emocionalno je preplavljen, što sve vodi ka nerealističnim očekivanjima od deteta i nižem kvalitetu brige (Krstić, Bugarski, Brkić i Obradović, 2013; Marvin \& Pianta, 1996).

Sem inicijalnog zahteva za reorganizacijom sistema brige, u razvoju i odrastanju deteta, pa i porodice u celini, nameću se brojni zahtevi za brigom koji su specifični za roditelje dece sa smetnjama u razvoju i mnoštvo otežavajućih okolnosti u odnosu na te zahteve. Naime, oni su kontinuirano konfrontirani sa potrebama deteta koje su često nejasne i daleko drugačije nego potrebe dece tipičnog razvoja, pa stoga roditelji nisu uvek sigurni kako da ih zadovolje. Neretko se karakteristike razvojne smetnje kao što su teškoće u komunikaciji, izostajanje povratne informacije od strane deteta, smanjena sposobnost tumačenja socijalnih signala itd., upliću između signalnih ponašanja deteta i odgovora roditelja i rezultuju u smanjenoj senzitivnosti i šansi adekvatnog odgovora (van Ijzdendoorn et al., 2007).

Istraživanja su pokazala da roditelji koji brinu o deci sa smetnjama u razvoju češće se suočavaju sa stresom i različitim kriznim događajima, češće pate od depresivnih stanja, češće imaju probleme u partnerskom odnosu i razvode se, od roditelja dece optimalnog razvoja (Dumas, Wolf, Fisman, \& Culligan, 1991; Olsson \& Hwang, 2001; Reichman, Corman \& Noonan, 2004). S druge strane depresivni roditelji, roditelji koji izveštavaju o niskom kvalitetu bračne relacije i slaboj socijalnoj podršci su cesto roditelji koji su manje posvećeni roditeljskoj ulozi, pokazuju manje zadovoljstva u interakciji sa detetom i imaju manje kapaciteta da reaguju senzitivno da detetove potrebe (Bradley et al., 1997; Corwyn \& Bradley, 1999).

Uprkos ovim potrebama, još uvek je nedovoljno razvijen sistem podrške porodicama dece sa smetnjama u razvoju, što je delom posledica negativnih stavova 
društva prema ovim porodicama. I u istraživanjima $\mathrm{u}$ inostranstvu roditelji izveštavaju da ne postoji dovoljno kvalitetna saradnja sa ustanovama koje brinu o detetu, što je posledica percipirane ekspertske pozicije profesionalnog osoblja u odnosu na roditelja umesto očekivanog saradničkog odnosa (Case, 2000) i nedovoljne količine informacija koju stručnjaci pružaju roditeljima, kako o specifičnostima dijagnoze, tretmanskom procesu, značenju dijagnoze za porodično funkcionisanje, tako i o ustanovana koje pružaju podršku (Davies \& Hall, 2005; Hall \& Graff, 2011; Pain, 1999). Rezultati istraživanja su pokazali i da su očekivanja roditelja od obrazovnih ustanova često drugačija u odnosu na praksu, u domenu ciljeva i brige o detetu (Soodak \& Ervin, 1995), i da roditelji imaju potrebu da se više uključe u donošenje odluka i obrazovni proces svog deteta (Danklefsen, 2008; Fish, 2006; Valle, 2002). Roditelj koji ima percepciju da je prepušten sam sebi, često nema kapaciteta da pruži adekvatnu brigu. Kod nas istraživanja na ovu temu gotovo i da nema.

U istraživanju Corwyn i Bradley (1999), istraživane su relacije dimenzija socioemocionalne posvećenosti sa faktorima koji imaju izvor u socijalnom kontekstu, temperamentu deteta i razvojnim karakteristikama, kvalitetu roditeljskog saveza, zaposlenju majke i oca. Ulaganje napora na poslu, kod očeva pokazalo se da značajno utiče na prihvatanje roditeljske uloge i deteta, dok se kvalitet roditeljskog saveza pokazao kao značajan prediktor više senzitivnosti. Temperament deteta i zaposlenje majke su se pokazali kao prediktori prihvatanja roditeljske uloge i deteta, a kao i kod očeva kvalitet roditeljskog saveza je uticao na senzitivnost.

Majke su najčešće od rođenja deteta primarni staratelji i u skladu sa tom ulogom, one provode više vremena sa detetom, a u tradicionalnim društvima, kao što je naše, i dalje se smatra da su žene zadužene za brigu o deci, dok su očevi uključeni u manjoj ili većoj meri. Kako su ženska i muška deca još uvek prilično tradicionalno i rodno uslovljeno odgajaju, ona odrastaju i postaju roditelji sa različitim idejama šta roditeljstvo jeste. Očevi roditeljstvo posmatraju kao nešto „što rade“, a majke nešto „što jesu“ (Corwyn \& Bradley, 1999). Sem toga očevi često izveštavaju da svoju ulogu vide kao pomaganje primarnom staratelju- majci, u brizi o detetu (Lamb \& Oppenheim, 1989). U skladu sa tim, pretpostavka je da će socioemocionalna posvećenost biti viša kod majki, nezavisno od grupe roditelja kojima pripadaju -roditeljima dece sa smetnjama u razvoju odnosno roditeljima dece tipičnog razvoja.

Cilj ovog istraživanja bio je da se ispita da li postoje značajne razlike u kvalitetu socioemocionalne posvećenosti između roditelja dece sa smetnjama u razvoju i roditelja dece tipičnog razvoja, kao i da se ispita da li postoje značajne razlike između majki i očeva u obe grupe. Ovakav cilj je postavljen iz potrebe za boljim razumevanjem kvaliteta brige o deci sa smetnjama u razvoju i stvaranja novih okvira za planiranje i realizaciju programa podrške za roditelje dece sa smetnjama u razvoju kako bi se razvijali kapaciteti roditelja za brigu o deci. 


\section{METOD}

\section{Uzorak}

U istraživanju je učestvovalo 202 roditeljska para. Od toga je bilo 75 parova roditelja dece sa smetnjama u razvoju, za koje je izrađene mere individualizacije ili individualni obrazovni plan i 127 parova roditelja dece tipičnog razvoja. Porodice su regrutovane od strane vaspitača i stručnih saradnika u predškolskim ustanovama. Porodicama je jasno obrazložen cilj istraživanja i tražena je saglasnost za učestvovanje u istraživanju. Bateriju upitnika su dobijale majke i očevi odvojeno, popunjavali su naknadno i u koverti vraćali vaspitačima.

Što se tiče polne i starosne strukture dece, u uzorku porodica dece sa smetnjama bilo je tri četvrtine roditelja dečaka $(75 \%)$ i jedna četvrtina roditelja devojčica (25\%), prosečnog uzrasta 7.8 godina, dok je u uzorku porodica dece tipičnog razvoja bilo oko polovina roditelja dečaka $(47 \%)$ i polovina roditelja devojčica (53\%), prosečnog uzrasta 6.8 godina. Porodice su u proseku imale po dvoje dece. U ukupnom uzorku, u 116 porodica su zaposlena oba roditelja, u 52 porodice zaposlen samo otac, u 12 zaposlena samo majka i u 22 nezaposleni oboje. U uzorku porodica dece sa smetnjama u razvoju u 25 porodica su zaposlena oba roditelja, u 28 porodica samo otac, u 7 porodica samo majka i u 15 porodica oba roditelja nezaposlena.

\section{Varijable i instrumenti}

U skladu sa ciljevima i hipotezama istraživanja, uključene su sledeće varijable:

1.Populacija: roditelji dece sa smetnjama u razvoju/roditelji dece tipičnog razvoja

2.Pol roditelja: ženski/muški

3.Kvalitet brige o detetu: operacionalizovan preko socioemocionalne posvećenosti koja se odnosi na radost i zadovoljstvo, želju da se provodi vrelme sa detetom, iskazivanje emocija, senzitivnost na detetove potrebe, prihvatanje roditeljske uloge i deteta, kao i delovanje u najboljem interesu deteta.

Socioemocionalna posvećenost roditelja detetu je merena i operacionalizovana preko Upitnika o socioemocionalnoj posvećenosti roditelja detetu (PIC - Parental Investment in Child Questionaire, Bradely i sar, 1997), koji je nastao iz potrebe za instrumentom koji bi na adekvatan način merio karakteristike kvaliteta brige roditelja. U originalnoj verziji ovaj upitnik se sastoji od 24 stavke. U prethodnim istrazivanjima su nakon psihometrijskih provera iz skale isključene dve stavke koje su originalno pripadale subskali separaciona anskiznost, tako da je u ovom istrazivanju primenjena verzija koja se sastoji od 22 stavke sa četvorostepenim odgovorima Likertovog tipa (Mihić, 2009), na kojima viši skor govori o višem kvalitetu socioemocionalne posvećenosti roditelja. Konstrukt socioemocionalna 
posvećenost, kao predmet merenja ovog upitnika, meri kvalitet i karakteristike sistema brige staratelja, koji ima direktan efekat na kvalitet afektivne vezanosti i socioemocionalni razvoj deteta. Na našoj populaciji ovaj instrument je pokazao zadovoljavajuće metrijske karakteristike i visoku pouzdanost- Kronbahov alfa koeficijent pouzdanosti iznosi 0.87 . Konstrukt socioemocionalne posvećenosti, operacionalizovan je preko četiri dimenzije:

- Prihvatanje uloge roditelja i prihvatanje deteta-koja podrazumeva spremnost roditelja da definiše svoju ulogu, prepozna zahtevnost uloge i integriše je sa ostalim ulogama (npr. "Bilo je teško izaći na kraj sa zahtevima koji su postavljeni pred porodicu, a tiču se brige o detetu.");

- Senzitivnost, responsivnost i znanje o potrebama deteta- podrazumeva znanje roditelja o razvojnim potrebama i kapacitetima deteta, te u skladu sa tim sposobnost roditelja da razume detetove signale i da adekvatno odgovara na njih (npr. "Mnogo roditelja drži svoje dete, grli ga i nosi i suviše.");

- Separaciona anksioznost- operacionalizovana kao briga i uznemirenost zbog potencijalnog ili realnog odvajanja od deteta (npr. "Kad idem negde uglavnom vodim dete sa sobom.”);

- Zadovoljstvo roditeljskom ulogom i interakcijom sa detetom- podrazumeva uživanje u ulozi roditelja i interakciji sa detetom (npr. "Maženje sa mojim detetom je zabavnije od većine stvari koje radim.”) (Bradley i sar, 1997).

\section{REZULTATI}

Ispitivanje razlika u ukupnom skoru na socioemocionalnoj posvećenosti, $\mathrm{i}$ eventualna struktura razlika, kako između grupe roditelja dece sa smetnjama i roditelja dece tipičnog razvoja tako i između majki i očeva u okviru obe grupe, sprovedeno je analizom varijanse i kanoničkom diskriminativnom analizom.

U Tabeli 1. dat je prikaz deskriptivnih pokazatelja grupa u domenu socioemocionalne posvećenosti. Dobijena je statistički značajna razlika između roditelja dece sa smetnjama u razvoju i roditelja dece tipičnog razvoja, u pravcu višeg skora na socioemocionalnoj posvećenosti kod roditelja dece tipičnog razvoja (Tabela 2.). 
Tabela 1. Deskriptivni pokazatelji-socioemocionalna posvećenost

\begin{tabular}{lccccccccc}
\hline & \multicolumn{3}{c}{ Ukupno } & \multicolumn{3}{c}{ Majke } & \multicolumn{3}{c}{ Očevi } \\
\cline { 2 - 9 } Kategorija & $\mathrm{N}$ & $\mathrm{M}$ & $\mathrm{SD}$ & $\mathrm{N}$ & $\mathrm{M}$ & $\mathrm{SD}$ & $\mathrm{N}$ & $\mathrm{M}$ & $\mathrm{SD}$ \\
\hline $\begin{array}{l}\text { Porodica dece sa } \\
\text { smetnjama u razvoju }\end{array}$ & 126 & 52.52 & 7.67 & 63 & 51.97 & 8.52 & 63 & 53.06 & 6.74 \\
\hline $\begin{array}{l}\text { Porodica dece } \\
\text { tipičnog razvoja }\end{array}$ & 226 & 55.11 & 6.77 & 118 & 54.65 & 6.56 & 108 & 55.6 & 6.98 \\
\hline
\end{tabular}

Tabela 2. Prikaz značajnosti efekata pripadnosti grupi i pola, $i$ interakcijskog efekta na nivo socioemocionalne posvećenosti

\begin{tabular}{lccccc}
\hline & SS & Df & MS & F & P \\
\hline Grupa* & 542.64 & 1 & 542.64 & 10.72 & .001 \\
Pol** $_{\text {Grupa x Pol }}^{87.45}$ & 1 & 87.45 & 1.73 & .190 \\
\hline
\end{tabular}

*Grupa-roditelji dece sa smetnjama u razvoju/roditelji dece tipičnog razvoja **Pol-majke/očevi

Analizom varijanse pokazano je da postoji značajan glavni efekat pripadnosti grupi roditelja dece sa smetnjama u razvoju odnosno roditelja dece tipičnog razvoja, na kvalitet socioemocionalne posvećenosti, dok nije dobijen značajan glavni efekat pola- majke i očevi dece se ne razlikuju značajno u socioemocionalnoj posvećenosti. Nije dobijen ni efekat interakcije pripadnosti grupi i pola na kvalitet socioemocionalne posvećenosti.

Diskriminativnom analizom izdvojena je jedna značajna diskriminativna funkcija (Tabela 3.), a analizom strukture razlika pokazano je da se roditelji dece sa smetnjama u razvoju i roditelji dece tipičnog razvoja razlikuju najviše na dimenziji prihvatanje roditeljske uloge (Tabela 4.)

\section{Tabela 3. Prikaz značajnosti diskriminativnih funkcija}

\begin{tabular}{ccccc}
\hline Funkcija & Wilksova $\lambda$ & $\mathrm{F}$ & $\begin{array}{c}\text { Broj stepeni } \\
\text { slobode }\end{array}$ & Nivo značajnosti \\
\hline $\mathbf{1}$ & .94 & 5.68 & 4,346 & .000 \\
\hline
\end{tabular}


Tabela 4. Matrica strukture diskriminativne funkcije

\begin{tabular}{lc}
\hline & Funkcija \\
Prihvatanje uloge & $\mathbf{9 3}$ \\
Senzitivnost & .13 \\
Separaciona anksioznost & -.22 \\
Zadovoljstvo & -.21 \\
Tabela 5. Centroidi grupa \\
rove na diskriminativnoj funkciji (Tabela 5). \\
\multicolumn{2}{c}{ Funkcija } \\
dece sa smetnjama u razvoju & -.342 \\
\end{tabular}

\section{DISKUSIJA I ZAKLJUČAK}

Postoje brojni faktori koji mogu uticati na socioemocionalni razvoj dece, a na rani kvalitet brige u velikoj meri se oslanjaju dalji kapaciteti za socioemocionalni razvoj (Marshall, 2004). Roditelji dece sa smetnjama u razvoju su često pod rizikom za nižim kvalitetom brige, zbog činilaca koji potencijalno doprinose tome da roditeljstvo dece sa smetnjama u razvoju bude veći izazov nego roditeljstvo dece tipičnog razvoja. Ovo istraživanje je imalo za cilj da ispita kakav je kvalitet socioemocionalne posvećenosti roditelja dece sa smetnjama u razvoju u odnosu na roditelje dece tipičnog razvoja, kao i da pruži nalaze o razlikama u socioemocionalnoj posvećenosti među roditeljima.

Dobijenim rezultatima je potvrđena hipoteza o nižem kvalitetu brige, operacionalizovanom preko kvaliteta socioemocionalne posvećenosti, kod roditelja dece sa smetnjama u razvoju. Analiza varijanse je ukazala na značajan glavni efekat pripadnosti grupi za kvalitet socioemocionalne posvećnosti, dok se glavni efekat pola nije pokazao statistički značajnim- majke i očevi se ne razlikuju značajno u kvalitetu socioemocionalne posvećenosti. Ovaj podatak ukazuje na to da su porodice dece sa smetnjama kod nas, uprkos velikoj angažovanosti roditelja oko zbrinjavanja zdravlja deteta, u riziku od manjeg kvaliteta brige o detetu i podrške razvoju deteta.

I ranija istraživanja su ukazala na pravilnost da je u porodicama pod rizikom, pa tako i u porodicama dece sa smetnjama u razvoju verovatniji razvoj nesigurnog obrasca afektivne vezanosti, usled snižene senzitivnosti roditelja (Howe, 2006). Roditelji dece sa smetnjama u razvoju usled različitih psiholoških i 
sociodemografskih činilaca, kao što su blagostanje roditelja, karakteristike deteta, veličina porodice i sl. imaju snižen kapacitet za adekvatnu brigu (Choe et al., 2013). Metaanalitičke studije, rađene na istraživanjima vezanim za brigu o deci sa različitim smetnjama, ukazuju na podatak da je razvoj sigurnog obrasca afektivne vezanosti u ovoj populaciji dece prisutan u manje od 50\% slučajeva, dok je taj procenat u populaciji dece tipičnog razvoja nešto veći od $60 \%$ (van Ijzendoorn, Goldberg, Kroonenberg, \& Frenkel, 1992).

Kao značajan korelat nižeg kvaliteta brige u porodicama dece sa smetnjama u razvoju u mnogim istraživanjima se izdvaja stres roditeljstva (Baker et al., 2003; Howe, 2006; Rajić, Mihić, Kopunović-Torma, Branković, 2015). Stres roditeljstva je direktno povezan sa roditeljskom ulogom i utiče na lošije funkcionisanje porodice u celini (Skreden et al., 2012), razvoj nižeg kvaliteta roditeljstva, razvoj nesigurnog obrasca afektivne vezanosti, disfunkcionalan odnos između roditelja i deteta, te niži kvalitet života dece (Lopez, Clifford, Minnes \& Ouellette-Kuntz, 2008; Wiley \& Renk, 2007). Kako se stresori izazvani povećanim zahtevima u vezi brige za dete šire, roditelji mogu da se sve više osećaju depresivnim, bespomoćnim i/ili bezvrednim (Crnic, Friedrich, \& Greenberg, 2002), takvi roditelji često nemaju kapaciteta da pruže kvalitetnu brigu i negu detetu i njihovi odgovori na potrebe deteta često mogu biti nedosledni i siromašni. S obzirom na rezultat ovog istraživanja koji ukazuje na rizik od manjeg kvaliteta brige $u$ porodicama dece sa smetnjama u razvoju, u cilju planiranja kvalitetnih i usko specijalizovanih programa podrške za roditelje dece sa smetnjama u razvoju, između ostalog neophodno je sprovoditi sistematska istraživanja izraženosti i efekata stresa roditeljstva.

Kao što je već spominjano, od kvaliteta brige roditelja, u velikoj meri zavisi razvoj sigurnog obrasca afektivne vezanosti kao indikatora optimalnih uslova za razvoj. Razrešenje u odnosu na dijagnozu deteta predstavlja odnos roditelja prema dijagnozi u smislu kognitivne i emocionalne prorade dijagnoze i njenih implikacija na detetov razvoj i dalje funkcionisanje celokupne porodice (Pianta \& Marvin, 1993). Istraživanja su ukazala na značajnost odnosa između razrešenja majke, kao preduslova za viši kvalitet brige, i razvoja sigurnog obrasca afektivne vezanosti deteta (Marvin \& Pianta, 1996). Nalazi ovih istraživanja su ukazali da je u grupi majki sigurno afektivno vezane dece oko $82 \%$ razrešenih i $19 \%$ nerazrešenih, što bi značilo da su deca $81 \%$ nerazrešenih majki nesigurno afektivno vezana (Krstić, 2013). Ovo je podatak koji izdvaja majčin, odnosno roditeljski status razrešenja kao značajan korelat višeg kvaliteta brige i razvoja sigurnog obrasca afektivne vezanosti. Jedan od indikatora statusa razrešenja roditelja može biti i prihvatanje uloge roditelja i prihvatanje deteta. U ovom istraživanju analiza strukture razlika $\mathrm{u}$ socioemocionalnoj posvećenosti je dala značajan doprinos u vidu izolovanja prihvatanja roditeljske uloge i deteta kao dimenzije koja najviše zasićuje diskriminativnu funkciju, po kojoj se roditelji dece sa smetnjama u razvoju i roditelji dece tipičnog razvoja najviše razlikuju. 
Prihvatanje roditeljske uloge i deteta podrazumeva spremnost da se definiše uloga roditelja i integriše sa ostalim ulogama, kao i procenu zahtevnosti koju ova uloga ima (Bradley et al., 1997). Tranzicija u roditeljstvo je razvojno očekivana kriza i ona podrazumeva nekoliko razvojnih zadataka koji se tiču reorganizacije mentalnih reprezentacija o sebi kao roditelju i brizi o detetu, ali i reorganizacije porodičnog funkcionisanja i mnogih drugih aspekata života novih roditelja. Po rođenju deteta, svi roditelji se nalaze pred zahtevom za promenom unutrašnjeg radnog modela brige formiranog u trudnoći, koji podrazumeva najčešće idealizovana očekivanja od specifičnosti uloge roditelja, od deteta i odnosa sa njim. Usled iskustva sa realnim detetom, formirane reprezentacije bi trebale $u$ većoj ili manjoj meri da se redefinišu. Neretko čak i roditelji dece tipičnog razvoja imaju teškoće u rešavanju ove razvojne krize, a kod roditelja dece sa smetnjama u razvoju, taj zahtev je nešto složeniji jer podrazumeva potpuni gubitak predstave o idealnom detetu, i nameće se zahtev za prilagođavanjem na brigu o detetu sa razvonim smetnjama. On je veći, s obzirom na veću diskrepancu između zamišljenog (idealnog) i realnog deteta, stoga je ovim roditeljima neretko identifikovanje sa roditeljskom ulogom iscrpljujuće i prevelik zahtev. Sem toga, roditelji dece tipičnog razvoja i pored svih teškoća, roditeljstvo pozitivno konotiraju, znaju da je njihovo dete zdravo i da će jednog dana postati samostalno, dok su roditelji dece sa smetnjama u razvoju suočeni sa činjenicom da će njihovo dete možda zauvek biti zavisno od brige nekog drugog (Krstić, 2013).

Nakon saznavanja za dijagnozu deteta, roditelji izveštavaju o reakcijama koje su vrlo slične reakcijama na gubitak bliske figure- šok, neverica, kao i na kontinuirano osećanje tuge (Marvin \& Pianta, 1996; Rentinck et al., 2008). Ta tuga je intenzivna i dugotrajna i ima tendenciju da se ponovo javlja u periodima kada je kod dece tipičnog razvoja očekivan prelazak na nove razvojne faze (Krstić, 2013).

Kako bi roditelj prilagodio svoj model brige u skladu sa brigom o realnom detetu sa hroničnim razvojnim smetnjama, potrebno je da se adaptira na saznanje dijagnoze deteta, da reši zadatak kognitivne i emocionalne prorade dijagnoze. Kognitivno da razume implikacije detetove dijagnoze, a emocionalno da ispolji i prihvati sva osećanja vezana za razumevanje dijagnoze (Barnett et al, 2003). Roditelj koji je prihvatio dijagnozu deteta sa svim njenim implikacijama, prihvatio je sebe kao roditelja deteta sa smetnjama u razvoju, ima realističan pogled na razvojne potrebe i zdravstveno stanje deteta, i u skladu sa tim može da prilagodi svoja očekivanja od deteta i ulogu roditelja konkretnom detetu. Ako roditelj nije razrešen u odnosu na dijagnozu, on ne može da podrži detetove razvojne potrebe pa je često nerealističan u očekivanjima od deteta, on u svom procesu tugovanja stagnira i fokusira se konstantno na trenutak saznavanja dijagnoze što ga emocionalno preplavljuje (Krstić i sar, 2013; Marvin \& Pianta, 1996) i posledično još više odlaže proces prihvatanja roditeljske uloge i deteta.

Marvin i Pianta, sa osnovom u Bolbijevoj teoriji afektivne vezanosti, razvili su tehniku za procenu odnosa roditelja prema dijagnozi deteta (Reaction to 
Diagnosis Interview; Pianta \& Marvin, 1993), prema kojoj se upravo navedene reakcije roditelja mogu svrstati u kategoriju razrešenih roditelja ili nerazrešenih. Istraživanja pokazuju da na razrešenost majke u odnosu na dijagnozu deteta utiče stres prepoznat $\mathrm{u}$ domenu roditeljstva, bračno zadovoljstvo supružnika, i nivo kvaliteta socijalne podrške, a razrešenost generalno ima uticaja na sve odnose u porodici i socijalnom okruženju (Sherran, Marvin \& Pianta, 1997). Efekti razrešenosti roditelja prepoznaju se kao kvalitet senzitivnosti roditelja, realistično očekivanje od deteta, zadovoljstvo roditelja itd. Nerazrešenost majke u odnosu na dijagnozu deteta usko je povezana sa formiranjem nesigurnog obrasca afektivne vezanosti kod deteta (Marvin \& Pianta, 1996).

Dakle razrešenost u odnosu na dijagnozu ostvaruje značajan efekat na roditeljsku percepciju i prihvatanje uloge. U ovom istraživanju je pokazano da za roditelje dece sa smetnjama u razvoju jedan od najznačajnijih izazova predstavlja prihvatanje roditeljske uloge i deteta i to je rezultat koji ukazuje da u porodicama dece sa smetnjama u razvoju postoji povećan rizik od nerešavanja razvojnog zadatka prihvatanja roditeljske uloge i reorganizacije modela brige u odnosu na zahteve za brigom o realnom detetu. Neadekvatno rešenje ovog zadatka je jedan od indikatora nerazrešenosti roditelja. $U$ našoj populaciji istraživanja pokazuju da se razrešenost roditelja javlja u oko $60 \%$ slučajeva, dok se nerazrešen odnos javlja u između 30\% i 40\% slučajeva (Krstić, 2013; Mihić i sar., 2015). Ovakvi rezultati, uz rezultate ovog istraživanja, otvaraju vrata za planiranje intervencija i programa podrške koji bi akcenat stavili na značaj procene i praćenja statusa razrešenja roditelja kao potencijalnog činioca razvoja kvaliteta brige o detetu. $\mathrm{Na}$ taj način bi se pratio proces prihvatanja roditeljske uloge i reorganizacije unutrašnjeg radnog modela brige $i$ jačali bi se kapaciteti za brigu roditelja dece sa smetnjama u razvoju.

Sa porastom svesti o benefitima rane intervencije kod dece sa smetnjama $u$ razvoju, svedoci smo pojave sve većeg broja različitih programa usmerenih na podršku deci sa smetnjama u razvoju. Ta podrška, bilo da potiče iz medicinskog ili socijalnog modela, pruža se deci od najranijeg uzrasta i svakako je od velikog značaja. Postoje različiti servisi i socijalne usluge na nivou lokalne zajednice koje se realizuju u cilju pružanja podrške i pomoći deci sa smetnjama u razvoju i njihovim porodicama radi poboljšanja kvaliteta života. Najčešće pružana usluga za decu sa smetnjama u razvoju je Dnevni boravak, koja se realizuje u 62 lokalne zajednice u Srbiji (Republički zavod za socijalnu zaštitu). Pružaoci usluga su najčešće institucije socijalne zaštite, centri za socijalni radi i udruženja osoba sa invaliditetom. Podrška deci sa smetnjama u razvoju uglavnom je usmerena na finansijsku podršku porodici, omogućavanje inkluzivnog obrazovanja, pružanje usluga dnevnog boravka itd. Sem toga, svedoci smo i činjenice da u čitavoj priči o ranoj intervenciji za porodice dece sa smetnjama u razvoju, roditelji ostaju u senci. Iako su oni ključna karika u lancu brige o detetu, roditelj koji nije prihvatio svoju ulogu i brigu o realnom detetu- detetu sa razvojnim smetnjama, najčešće nema kapaciteta da podrži razvojne potrebe deteta. U takvoj situaciji benefiti od 
usluga podrške koje roditelj ima su u određenoj meri manji. Pa tako na primer, od roditelja koji su nerazrešeni se često ne može očekivati dobar saradnički odnos sa ustanovama koje brinu o detetu- vrtićima, školama jer on ne razume potrebe deteta i nije dovoljno senzitivan na njih (Mihić i sar., 2015). Kroz istraživanja se saradnja roditelja i relevantnih ustanova pokazala kao niskog kvaliteta, usled percipirane ekspertske pozicije vaspitača (Case, 2000). Sem toga, barijera ka kvalitetnoj saradnji roditelja i ustanova često je i percepcija roditelja da ne dobijaju dovoljnu količinu informacija od stručnjaka, kako o specifičnostima dijagnoze, tretmanskom procesu, značenju dijagnoze za porodično funkcionisanje, tako i o ustanovana koje pružaju podršku (Davies \& Hall, 2005; Hall \& Graff, 2011; Pain, 1999). Očekivanja roditelja u tom domenu su se generalno pokazala kao različita u odnosu na praksu, naročito kada je reč o ciljevima i brizi o detetu (Soodak \& Ervin, 1995). Kada je reč o učešću u smislu donošenja odluka u vezi vaspitno-obrazovnog procesa deteta, roditelji imaju potrebu da se više uključe (Danklefsen, 2008; Fish, 2006; Valle, 2002).

Relevantne ustanove koje planiraju i realizuju neke vrste programa podrške za roditelje prepoznaju potrebe roditelja, ali dominantno u svetlu podrške koja podrazumeva fizičku pomoć u brizi o detetu. Roditeljima su dostupne usluge, realizovane u okviru projektnih aktivnosti pod okriljem različitih udruženja osoba sa invaliditetom, kao što su: Pomoć u kući, čuvanje dece, usluga Predah, kako bi se roditeljima olakšao svakodnevni život i omogućilo vreme i prostor za bolje balansiranje ulogama i kontakt sa drugim članovima porodice. Iako su ovi programi, u osnovi prilično korisni, zvanično ne postoje programi koji se bave psihološkom podrškom roditeljima dece sa smetnjama u razvoju iako je to i kako istraživanja pokazuju, podrška koja bi roditeljima najviše značila (Jabery, Arabiat, Khamra, Betawi \& Jabbar, 2014).

U inostranstvu mreža podrške roditeljima dece sa smetnjama u razvoju mnogo je razvijenija i to u vidu savetodavnog, terapijskog rada, grupa podrške itd. Roditelji pokazuju potrebu za ranim intervencijom, porodičnim savetovanjem i podizanjem svesti zajednice (Jabery et al., 2014). Istraživanja pokazuju da su najčešće usluge koje se pružaju roditeljima dece sa smetnjama u razvoju redom: individualno savetovanje, grupe podrške, porodično savetovanje, različiti treninzi jačanja veština roditeljstva (Hensley, 2007). Rezultati ovog istraživanja direktno upućuju na potrebe roditelja za ovakvom vrstom usluga, i u smislu daljeg istraživanja otvaraju prostor za identifikovanje činilaca koji doprinose višem kvalitetu socioemocionalne posvećenosti, senzitivnosti i kvalitetu brige roditelja dece sa smetnjama u razvoju, u odnosu na koje će pomenute usluge podrške biti usmerene. 


\section{PARENTAL INVESTMENT IN CHILD AMONG PARENTS OF CHILDREN WITH DISABILITIES: DIFFERENCES BETWEEN MOTHERS AND FATHERS}

\section{SUMMARY}

Parents of children with disability are faced with care demands more challenging and much different than care demands in parenting typicaly developed child. Care quality and parental sensitivity are often lower in families of children with disabilities, than in families of tipicaly developed children, which results in higher incidence of insecure attachment. One of possible explanations lays in assumption that there are many psychological and sociodemographic factors affecting parents' capacity for caring. The main aim of this study was to examine the differences in care quality, measured through parental investment, between parents of children with disabilities and parents of typicaly developed children. According to the previous research results which suggests that mothers' and fathers' care quality provision differs, the next aim in this study was to examine the gender differences in parental investment. The sample consisted of 75 mothers and 75 fathers of children with disabilities and 127 mothers and 127 fathers of typicaly developed children. To assess the quality of parental investment in child we used PIC scale (Parental Investment and Child Questionnaire, Bradley, 1997). The results showed statisticaly significant difference in parental investment between parents of children with disability and parents of typicaly developed children $(\mathrm{F}=10.72 ; \mathrm{df}(1) ; \mathrm{p}<.01)$. Gender effect wasn't significant. Structure analysis showed that the two groups of parents differ mostly in Accepting parenting role and child ( $w \lambda=0.94$, $\mathrm{F}(4,346)=5.68, \mathrm{p}<.01)$. The results were interpreted according to theoretical starting point, in light of inner working models and accepting child's diagnosis. Results are suggesting that more research should be done on investigating factors that contribute to lower care quality in families of children with disabilities. The results were interpreted in the light of practical implications as well, raising a question of guidelines for planing interventions and programs to enhance parental sensitivity and care quality in families of children with disabilities.

Key words: Parents of children with disabilities, care quality, parental investment in child 


\section{LITERATURA}

Ainsworth, M. S. (1979). Infant-mother attachment. American psychologist, 34, 932-937.

Baker, B. L., McIntyre, L. L., Blacher, J., Crnic, K., Edelbrock, C., \& Low, C. (2003). Preschool children with and without developmental delay: behaviour problems and parenting stress over time. Journal of Intellectual Disability Research, 47, 217-230.

Barnett, D., Clements, M., Kaplan-Estrin, M., \& Fialka, J. (2003). Building new dreams: Supporting parents' adaptation to their child with special needs. Infants and Young Children, 16, 184-200.

Belsky, J. (1984). The determinants of parentning: a process model. Child development, 55, 83-96.

Belsky, J. (1999). Interactional and contextual determinants of attachment security. In: J., Cassidy, P.R., Shaver, (Eds.). Handbook of attachment: Theory, research, and clinical applications, (pp. 249-264). New York: Guilford Press.

Bowlby, J. (1982). Attachment and loss: retrospect and prospect. American journal of Orthopsychiatry, 52, 664-678.

Bradley, R.H., Whiteside-Mansell, L., Brisby, J.A. \& Caldwell, B.M. (1997). Parents' socioemotional investment in child. Journal of Marriage and Family. 59, 77-90.

Case, S. (2000). Refocusing on parent: What are the social issues of concern for parents with disabled child. Disability \& Society, 15, 271-292.

Choe, D.E., Olson, S.L.,\& Sameroff, A.J. (2013). Effects of early maternal distress and parenting on the development of children's self-regulation and externalizing behaviour. Developmental.Psychopathology. 25,437-453.

Clements, M., \& Barnett, D. (2002). Parenting and attachment among toddlers with congenital anomalies: Examining the Strange Situation and attachment Q-sort. Infant mental health journal, 23, 625-642.

Corwyn, R. F., \& Bradley, R. H. (1999). Determinants of paternal and maternal investment in children. Infant Mental Health Journal, 20, 238-256.

Corwyn, R.F., Bradley, R.H. (2002). Stability of maternal socioemotional investment in young children. Parenting: science and practice, 2, 27-46.

Crnic, K. A., Friedrich, W. N., \& Greenberg, M. T. (2002). Adaptation of families with mentally retarded children: A model of stress, coping, and family ecology. Best of AADD: Families and developmental delay: AA collection of notable AADD journal articles across the 20th century, 105-117.

Danklefsen, P., R. (2008). Perceptions of collaboration of parents of students with disabilities and service providers. Unpublished doctoral dissertation. Ashland University, Ashland, $\mathrm{OH}$.

Davis, N. O., \& Carter, A. S. (2008). Parenting stress in mothers and fathers of toddlers with autism spectrum disorders: Associations with child characteristics. Journal of autism and developmental disorders, 38, 1278-1291.

Dexter, C. A., Wong, K., Stacks, A. M., Beeghly, M., \& Barnett, D. (2013). Parenting and attachment among low-income African American and Caucasian preschoolers. Journal of Family Psychology, 27, 629-638.

Dumas, J. E., Wolf, L. C., Fisman, S. N., \& Culligan, A. (1991). Parenting stress, child behavior problems, and dysphoria in parents of children with autism, Down syndrome, behavior disorders, and normal development.Exceptionality: A Special Education Journal, 2, 97-110. 
Fish, W. W. (2006). Perceptions of parents of students with autism towards the IEP meeting: A case study of one family support group chapter. EDUCATION-INDIANAPOLIS THEN CHULA VISTA-, Vol. 127, 56-68.

Hall, H. R., \& Graff, J. C. (2011). The relationships among adaptive behaviors of children with autism, family support, parenting stress, and coping. Issues in Comprehensive Pediatric Nursing, 34, 4-25.

Hanak, N. (2012). Prenatalna afektivna vezanost i psihološki procesi tokom trudnoće: priprema za roditeljstvo. U: Stefanović-Stanojević, T., Mihić, I., Hanak, N. (Ur.), Afektivna vezanost i porodični odnosi: razvoj i značaj. (str. 57-81). Beograd: Centar za primenjenu psihologiju.

Hensley, C. (2007). Support systems for parents of children with special needs. Paper based on a program presented at the Association for Counselor Education and Supervision Conference. Columbus, $\mathrm{OH}$.

Howe, D. (2006). Disabled children, parent-child interaction and attachment.Child \& family social work, 11, 95-106.

Jabery, M. A. A., Arabiat, D. H., Khamra, H. A. A., Betawi, I. A., \& Jabbar, S. K. A. (2014). Parental Perceptions of Services Provided for Children with Autism in Jordan. Journal of Child and Family Studies, 23, 475-486.

Krstić, T. (2013). Majke hronično ometene dece: prihvatanje dijagnoze i prevladavanje stresa. Neobjavljena doktorska disertacija. Novi Sad: Filozofski fakultet.

Krstić, T., Bugarski, V., Brkić, N. I Obradović. B. (2013). Odnos majke prema detetovoj dijagnozi cerebralne paralize. Medicinski pregled, LXVI (3-4), 181-184.

Lamb, M.E., \& Oppenheim, D. (1989). Fatherhood and father-child relationships: Five years of research. In S.A. Cath, A. Gurwitt, \& L. Gunsberg (Eds.), Fathers and their families (pp. 11- 26). Hillsdale, NJ: Analytic Press.

Lopez, V., Clifford, T., Minnes, P. \& Ouellette-Kuntz, H. (2008). Parental stress and coping in families of children with and without developmental delays. Journal of Developmental Disabilities, 14, 99-104.

Marshall, N.L. (2004). The quality of early child care and children's development. Early Child Care and Development, 13, 165-168.

Marvin, R.S. \& Pianta, R.C. (1996). Mothers' reaction to their child's diagnosis: Relations with security of Attachment. Journal of Clinical Child Psychology, 25, 436-443.

Mihić I. (2009). Socioemocionalna posvećenost roditelja detetu. U: M.Zotović, I.Mihić, J. Petrović (ur). Psihološka procena porodice- mogućnosti i ograničenja. (23-33). Novi Sad: Filozofski fakultet.

Mihić, I., Halas, I., Jocović-Delić, B., Lukić, N., Stojić, O., Rajić, M., Krstić, T. (2015). Podrška porodicama dece sa smetnjama u razvoju: značaj roditeljskog odnosa prema dijagnozi. Rad prezentovan na 6. Međunarodnoj naučnoj konferenciji „Inkluzija u predškolskoj ustanovi i osnovnoj školi“, Sremska Mitrovica, Srbija

Mayseless, O. (2006). Studing parenting representations as a window to parents` internal working model of careiving. In: O.Mayseless (Eds.), Parenting representations: theory, research and clinical implications, (pp 3-41). New York: Cambridge University Press.

Olsson, M. B., \& Hwang, C. P. (2001). Depression in mothers and fathers of children with intellectual disability. Journal of Intellectual Disability Research, 45, 535-543.

Pain H. (1999). Coping with a child with disabilities from the parents' pespective: The function of information. Child: Care, health and development, 25, 299-312. 
Pianta, R.C. \& Marvin, R.S. (1993). Manual for classification of the reaction to diagnosis interview. University of Virginia

Rajić, M., Mihić, I., Kopunović Torma, D. (2015). Stres roditeljstva, koroditeljski savez i briga o detetu sa smetnjama u razvoju- rad poslat na 4. skup Savremeni trendovi u psihologiju, u Novom Sadu, oktobar 2015.

Reichman, N. E., Corman, H., \& Noonan, K. (2004). Effects of child health on parents' relationship status. Demography, 41, 569-584.

Sheeran, T., Marvin, R. S., \& Pianta, R. (1997). Mothers' Resolution of Their Childs's Diagnosis and Self-Reported Measures of Parenting Stress, Marital Relations, and Social Support. Journal of Pediatric Psychology, 22, 197-212.

Skreden, M., Skari, H., Malt, U. F., Pripp, A. H., Björk, M. D., Faugli, A., \& Emblem, R. (2012). Parenting stress and emotional wellbeing in mothers and fathers of preschool children. Scandinavian journal of public health, 40, 596-604.

Slade, A., Belsky, J., Aber, J. L., \& Phelps, J. L. (1999). Mothers' representations of their relationships with their toddlers: Links to adult attachment and observed mothering. Developmental psychology, 35, 611-619.

Solomon, J., \& George, C. (1996). Defining the caregiving system: Toward a theory of caregiving. Infant Mental Health Journal, 17, 183-197.

Valle, J., W. (2002). IDEA and collaboration a Bakhtinian perspective on parent and professional discourse. Journal of Learning Disabilities, 35, 471-481.

Van IJzendoorn, M. H., Rutgers, A. H., Bakermans-Kranenburg, M. J., Swinkels, S. H., Van Daalen, E., Dietz, C., Naber, F.B.A, Buitelaar, J.K, \& Van Engeland, H. (2007). Parental sensitivity and attachment in children with autism spectrum disorder: Comparison with children with mental retardation, with language delays, and with typical development. Child Development, 78, 597-608.

Van IJzendoorn, M. H., Goldberg, S., Kroonenberg, P. M., \& Frenkel, O. J. (1992). The relative effects of maternal and child problems on the quality of attachment: A meta-analysis of attachment in clinical samples. Child development, 63, 840-858.

Wiley, R., \& Renk, K. (2007). Psychological correlates of quality of life in children with cerebral palsy. Journal of Developmental and Physical Disabilities, 19, 427-447. 